\title{
Study of behavioral patterns and infection analyses in anopheline species involved in the transmission of malaria in Buriticupu and São José de Ribamar municipality, Maranhão State, Brazil
}

\author{
Vera Lúcia Lopes de Barros® ${ }^{\circledR}$, Fábio Medeiros da Costa², Antônio Rafael da Silva¹, Eloisa da Graça Rosário \\ Gonçalves' ${ }^{1}$, Denilson da Silva Bezerra ${ }^{3}$, Elias Seixas Lorosa ${ }^{4} \&$ Wanderli Pedro Tadei ${ }^{5}$
}

1. Centro de Referências em Doenças Infecciosas e Parasitárias, Universidade Federal do Maranhão. 2. Oikos Consultoria e Projetos. 3. Departamento de Oceanografia e Limnologia, Universidade Federal do Maranhão. 4. Departamento de Entomologia, Fundação Oswaldo Cruz - FIOCRUZ. 5. Laboratório de Malária e Dengue, Instituto Nacional de Pesquisas da Amazônia - INPA.

EntomoBrasilis 13: e0820 (2020)

\section{Edited by:}

Jeronimo Augusto Alencar

Article History:

Received: 17.x.2018

Accepted: 22.i.2020

Published: 11.ii.2020

\section{Corresponding author:}

Vera Lúcia Lopes de Barros

७veralopes.bio@gmail.com

(1) orcid.org/0000-0003-1028-7255

Funding agencies:

* Fundação Nacional de Saúdel Ministério da Saúde do Brasil and to the Secretaria de Estado do Maranhão

\begin{abstract}
Anopheles darlingi Root and Anopheles aquasalis Curry are the main vectors of malaria that occur in the State of Maranhão. Entomological surveys based on the behavior and infectivity of these vectors are important for the elaboration of disease control strategies. The objectives of this work were to study the behavioral patterns of mosquitoes, determining population and hematophagic peaks, dietary preferences, infectivity rate and characterization of breeding sites in two municipalities in the State of Maranhão: Buriticupu and São José of Ribamar. Larvae and pupae were collected in breeding sites and adult females in home environments. Mosquito behavior, their dietary preferences and Plasmodium spp. infection rates were analyzed. The vegetation and physicochemical patterns in the breeding sites found are in agreement with those described for species from the Amazon region and the Brazilian Atlantic coast. Anopheles darlingi was the most prevalent mosquito in Buriticupu breeding and home environments. This species was found mainly fed on human blood and naturally infected with Plasmodium vivax Grassi \& Feletti and Plasmodium falciparum Welch. Anopheles aquasalis was more frequent in breeding sites in São José de Ribamar, as well as in home environments, whose specimens were mainly fed with human and bird blood. The main peaks of mosquito occurrence in Buriticupu were between 6 pm to 9 pm and in São José de Ribamar we did not record a definite peak. In the first municipality A. darlingi showed dominance over Anopheles albitarsis Lynch Arribálzaga s.l., Anopheles oswaldoi Peryassú, Anopheles nuneztovari Gabaldón and Anopheles evansae Brèthes, besides presenting a correlation with rainfall. In the second municipality, A. aquasalis was dominant over A. albitarsis s.l. and there was a correlation between these two species and the rainy season. We conclude that the collected data contribute to elucidate the dynamics of malaria transmission in the region and guide the control actions directed to the elimination of the disease in the country.
\end{abstract}

Keywords: Behavior; Blood Meal; Ecology; Parasite; Vector.

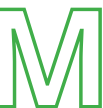
osquitoes which belong to Anopheles genus have a relevant importance as vectors in public health, due to the potentiality that they must transmit plasmodia parasites that cause the human malaria (FoRATIINI 2002). There were cataloged 57 species of anopheline in Brazil. Among them, at least two were recognized as the main malaria vectors: Anopheles darlingi Root, with a vast occurrence in the Amazonian interiors and in Brazil as a whole (DAvis 1931; HiwATS \& BRETAS 2011) and Anopheles aquasalis Curry, with a restricted distribution in the coastal strip and adjacencies (GALVÃo et al. 1942; SINKA et al. 2010).

The studies of malaria vectors are relevant for the biology knowledge, the behavior of species and the dynamic transmission of plasmodia parasites in each locality, helping in this way to elucidate the disease chain, the prediction of outbreaks and the guidance of control actions (BARBOSA et al. 2014, 2016). The entomological parameters such as density, anthropophilia, zoophilia, peaks of hematophagic activity, seasonal variations, infection rate and blood-feeding patterns are among the most frequent for the determination of the vector species (BARBosa et al. 2014).

In these studies, the relationship between the reduction in density of this group and the Amazonian rainy period was demonstrated, being more evident for the adult forms than the immature forms, since in the rainy season these insects are displaced from permanent breeding sites, from the mainland for lakes and ponds that form along river banks during floods. As the waters rise above the level of the flooded areas they originate the temporary breeding sites located in the middle of the forest. The availability of shelters or breeding sites in the rainy season facilitates the increase of breeding sites and the extension of anopheline occurrence, with a reflection on the prevalence of malaria, as it provides greater contact between man and vector. This is due to the fact that in regions where permanent breeding sites are distanced from human dwellings during the rainy season by 
the formation of temporary breeding sites, these are close to human dwellings intensifying human contact / vector. The pioneering studies performed by GaLVão et al. (1942) and DEANE et al. (1948) concluded that the intense reproduction of $A$. darlingi during the rainy season is associated with the numerous breeding sites in the region during this period, as well as the presence of this vector associated with anthropic action, which promotes changes in the natural habitat of mosquitoes.

These factors condition the emergence of new cases and the onset of epidemics. The process of marked environmental changes, according to Póvos et al. (2003), in the natural environment of the municipality of Belém, conditioned the resurgence of $A$. darlingi from the 90 s (twentieth century), after more than twenty years without registration of this species in this area. With environmental impacts, new outbreaks of malaria transmission emerged with possible influence on the cast of local species and changes in the distribution pattern, biology and behavior of these mosquitoes.

The disordered growth of many cities in malaria-endemic areas with inadequate housing conditions and the pressure of human populations, especially the poorest, on the environment, are conditioning factors for malaria maintenance. VITTOR et al. (2006, 2009) demonstrated in Peru that the pressure of human occupations and activities on the environment positively favors the $A$. darlingi vector that finds new conditions for proliferation, increasing the risks of disease transmission. These conditions were also recorded by TADEI et al. (2017) in many Brazilian Amazonian municipalities, which are responsible for the onset of epidemic outbreaks of malaria and their expansion to the major urban centers of the region.

The State of Maranhão, for example, illustrates this scenario well, because besides being considered the poorest in Brazil (IPEA 2019), it has significant areas with environmental degradation where there is active transmission of malaria, both in the coastal range of its territory and in the São José de Ribamar, which accounts for the majority of cases of the disease on the Atlantic coast and Buriticupu in the intracontinental zone. The aid of this paper was study the behavioral patterns of anopheline species in Buriticupu and São José de Ribamar municipalities, in Maranhão state, determining peaks of hematophagic activities, bloodfeeding preferences, natural infection rates, breeding sites characterization; the associations among the climate conditions and the presence of the Anopheles species; and the associations among the presence of the Anopheles species. The data of this work are part of a big project which studies the areas of malaria transmissions in Maranhão, being the first publication of the set or group performed by BARROs et al. (2015), in which was made the first register for $A$. aquasalis in Buriticupu. Thus, the data that mention the presence of this vector in that municipality was created from the set of this project.

\section{MATERIALS AND METHODS}

\section{Study areas}

The studies were conducted monthly from January in 2006 to February in 2011, in two localities of Maranhão State in Brazil:

A. Buritizinho village $\left(4^{\circ} 30^{\prime} 34,1^{\prime \prime}\right.$ S; $46^{\circ} 49^{\prime} 27,3^{\prime \prime}$ W) in municipality of Buriticupu. This locality is intercontinental; $300 \mathrm{~km}$ far away from the north Atlantic coast of Brazil and it is located between the borders of Pindaré and Buriticupu rivers, therefore, it is a semi-urban locality The access that place is by BR-222 Highway and by EF-315 dos
Carajás Railroad.

B. Guarapiranga village $\left(02^{\circ} 40^{\prime} 52,1^{\prime \prime} \mathrm{S} ; 44^{\circ} 08^{\prime} 43,9^{\prime \prime} \mathrm{W}\right)$ it is a semi-urban locality in municipality of São José do Ribamar. It is located in the coastal area of the Atlantic Ocean, inside of the Arraial Bay, in São Luís island complex. This area suffers the influence of tidal pulse and of several rivers whose outflow in the bay itself.

\section{Mosquito sampling}

Immature mosquitoes. The breeding sites selected for the study were located within 500 meters of human dwellings. In Buriticupu, these breeding sites were mainly characterized as riverbanks and backwaters. In São José de Ribamar, the most common breeding sites were marshes and mangroves.

The immature stages of anopheline were collected in their breeding sites between 7:00 am and 9:00 am through active search using a mosquito larvae dipper. With the obtained data we calculate the Larvae Index per Man Hour - LIMH by the formula:

LIMH= Number of larvae collected / Number of collecting technicians / Number of Collection Hours.

Adult mosquitoes. The adult mosquitoes collections took place intradomicile, peridomicile and in extra-domicile environments, in Buritizinho and in Guarapiranga, in the intradomicile and peridomicile. The peridomicile is the outdoor area surrounding the residence within 200 meters. Nevertheless, the extra domicile corresponds to an area greater than 200 meters radius. The techniques used for catching adult females were by Castro's aspirator: I) human landing catches (HLC), by trained technicians using personal protective equipment, and; II) active search for resting mosquitoes inside houses and in locations where there were animals taking a rest. Both were conducted during a period of time from 6:00 pm to 6:00 am (12 h), stratified or separated by a timetable or schedule; and a time from 6:00 pm to 10:00 pm (4 h). The studies were conducted in six human dwellings in each locality. There were obtained temperature data, relative humidity in the gathering environments, by means of digital thermo-hygrometers, and besides rainfall, in the database of the Instituto Nacional de Meteorologia - INMET.

The collection of mosquito samples conducted in this study is part of the routine work of technicians of the Fundação Nacional de Saúde - FUNASA, authorized by the Instituto Chico Mendes de Conservação da Biodiversidade - ICMBIO (SISBIO Number 18281-1).

\section{Mosquito identification}

The collected mosquitoes were taken to the entomology laboratory of the Universidade Federal do Maranhão - UFMA, in São Luís, for identification through the dichotomous keys of ForATTINI (2002).

\section{Breeding site characterization}

Breeding water information such as: temperature, hydrogen potential, electric conductivity, total dissolved solids, salinity, nitrogen compounds, ammonia and phosphorus, as well as the registration of aquatic plants, were also acquired by a descriptive characterization. The identification of vegetable was conducted in laboratories of the Universidade Federal do Maranhão - UFMA, in São Luís.

\section{Blood-feeding preferences}

SIQUEIRA's (1960) precipitin technique with modifications was made in order to identify the blood-feeding. Just some female examples of $A$. darlingi and $A$. aquasalis were used 
in this assay, in which their digestive tubes were removed submitted or kept down in solutions and centrifuged to obtain serum. Right away, they were examined with antisera of birds, mammals, reptiles and amphibians (Lorosa et al. 1998). The set of antisera and their respective tested titles were: anti-human 1:15,000; birds 1:10,000; dogs 1:15,000; cats 1:12,000; horses 1:16,000; goats 1:14,000; cattle $1: 15,000$; porks 1:10,000; sheep 1:8,000; lizards 1:14,000; rodents 1:17,000; possum 1:15,000; armadillos 1:15,000; frogs $1: 16,000$. All of the Precipitin tests were made in partnership with laboratories of pathology and parasitology of Fundação Oswaldo Cruz - FIOCRUZ, in Rio de Janeiro.

\section{Natural infection by Plasmodium spp.}

Estimating the rate of infection by Plasmodium ssp. in the anopheline female adults samples in both localities, was performed by the Nested-PCR technique, using specific primers according with the description of SNOUNOU et al. (1993). Then we calculate the Minimum Infection Rate MIR by the formula: MRI= ([number of positive pools/total specimens tested] $\times 1,000)$. These procedures were conducted in the Instituto Nacional de Pesquisas da Amazônia - INPA, in Manaus.

\section{Statistical analyzes}

The average of adult mosquitoes collected from January in 2006 to December in 2011, for both environments, were interpreted considering combinations with the average temperature indexes $\left({ }^{\circ} \mathrm{C}\right)$, relative humidity (\%) and precipitation $(\mathrm{mm})$. In order to quantify the associations among the climate conditions and the presence of the species and the coexistence of species, we obtained the simple and partial correlation estimates using the software R (R Development Core Team 2013).

\section{RESULTS}

\section{Mosquito sampling}

In total, 3,110 anopheline specimens were collected from adults and larvae distributed in nine species. They are: Anopheles albitarsis s.l. Lynch Arribálzaga, A. aquasalis, A. darlingi, Anopheles evansae Brèthes, Anopheles galvaoi Causey, Deane and Deane, Anopheles nuneztovari Gabaldón, Anopheles oswaldoi Peryassú, Anopheles strodei Roots and Anopheles triannulatus Neiva e Pinto.

The immature samples in the breeding sites totalized 190 anopheline larvae and five species collected. In Buriticupu, two breeding sites were positive and in São José de Ribamar, only one, out of a total of three, in each inspected locality.

The most frequent species was $A$. darlingi (41.1\%) and was found only in Buriticupu, where it represented $78 \%$ of the sample. In São José de Ribamar, the most frequent was $A$. aquasalis (61.3\%). The total of ILHH was 2.00, being 1.33 in Buriticupu and 0,64 in São José de Ribamar (Table 1).

2.290 females of anophelines were collected, being 2,845 (97\%) in Buriticupu and 75 (3\%) in São José de Ribamar. In the first locality, among the nine species, $A$. darlingi was the most collected (63.59\%) mainly in the peridomicile environment (62.96\%). In the second location, $A$. aquasalis was more prevalent (46.67\%) among the five species found, being also more frequent in the peridomicile environment (46.48\%) (Table 2).

\section{Breeding site characterization}

Regarding the water temperature of the breeding sites, very close values were found between, Buriticupu and São José de Ribamar, respectively $21^{\circ} \mathrm{C}$ and $20^{\circ} \mathrm{C}$. The $\mathrm{pH}$ varied slightly between the environments, respectively 5.18 and 5.91. The electrical conductivity was $0.263 \mathrm{~S} / \mathrm{m} 1$ for Buriticupu and 1.24 $\mathrm{S} / \mathrm{m}-1$ for São José de Ribamar. The total dissolved solids TDS 131.00 mg/L in Buriticupu and 23.50 mg/L in São José de Ribamar. The salinity was lower than 0.0001 in Buriticupu and 0.5/1.000 in São José do Ribamar. In the chemical analysis of nitrite in Buriticupu, were found mean values 0.25 $\mathrm{mg} / \mathrm{L}$, while in São José de Ribamar, the mean values were 0.75. Regarding nitrate, the Buriticupu samples quantified $1.42 \mathrm{mg} / \mathrm{L}$, while in São José de Ribamar, the values found were higher, $16.15 \mathrm{mg} / \mathrm{L}$. Regarding the ammonia content in the breeding sites, the average value in Buriticupu was 4.63 $\mathrm{mg} / \mathrm{L}$. For São José do Ribamar, this value was $21.61 \mathrm{mg} / \mathrm{L}$. The phosphorus content dissolved in Buriticupu breeding sites was on average $57.43 \mathrm{mg} / \mathrm{L}$, and $55.03 \mathrm{mg} / \mathrm{L}$ in São José do Ribamar (Table 3).

In relation to the presence of associated vegetation, the breeding sites in Buriticupu presented six families and six genera with greater dominance of the genus Cyperus sp. In São José de Ribamar, were found five families and five genera with Avicennia sp. and Rizophora sp. Just the genus Nymphaea was present in the breeding sites of both localities. All the evaluated breeding sites were classified as natural, in the soil, permanent or semi-permanent, whose margins are shaded due to the presence of Mauritia flexuosa, in Buriticupu and Avicennia sp. with Rizophora sp. in São José do Ribamar (Table 3).

\section{Blood-feeding preferences}

In Buriticupu, a total of 349 females were collected from A. darlingi engorged, 64 intradomicile, 139 in peridomicile, and 146 in extradomicile. About $A$. aquasalis 17 specimens were collected, 4 intradomicile and 13 in peridomicile. In intradomicile, $7.73 \%$ of $A$. darlingi collected, were fed human blood, followed by $5.17 \%$ with blood from birds and $2.86 \%$ with blood from cattle. In peridomicile, the highest number of $A$. darlingi fed with human blood (14.32), followed by dog blood (10.02\%) and the third highest value for bovine blood (6.59\%). The extradomicile data differ from the pattern observed in both environments, with the highest value for bird blood (13.75\%), followed by human blood (12.32\%) and cattle blood the third most frequent (6.59\%). Considering the general total, the $A$. darlingi by human blood represented $34.38 \%$ of the samples, followed by bird $-23.49 \%$ and cattle the third most frequent, representing $16.04 \%$ of the total. Whereas $A$. aquasalis, the percentage of specimens was very low, of which 13 specimens were found in peridomicile, fed mostly with human blood (58.82\%) and another 4 in intradomicile fed with human blood (11.76\%) and bird (11.76\%) (Table 4).

The analysis of the precipitin double reaction for bloodfeeding of $A$. darlingi and $A$. aquasalis allowed detecting that in intradomicile, 21 specimens $(14.38 \%)$ of $A$. darlingi were fed on rodent / human blood and 17 (11.64\%) on bird / human blood. Only one female from $A$. aquasalis fed on bird / human. In peridomicile, 19 specimens of $A$. darlingi $(13.01 \%)$ fed on bird / human blood, while 14 (9.58\%) fed on cat / bird and $6(4.10 \%)$ on poultry / cattle blood. In extradomicile, 20 specimens from $A$. darlingi (13.69\%) were engorged with human / skunk blood. There were also 18 specimens (12.32\%) of the skunk / bird combination; 16 (10.95\%) bird / cattle and $15(10.27 \%)$ of the bird / dog combination. Considering the general total of the double reactions, the $A$. darlingi per bird / human, represented $24.65 \%$ of the mosquitoes collected, followed by the skunk / bird combination (21.91\%) and $15.06 \%$ for the bird / cattle combination. For A. aquasalis reacted doubly only one specimen for the bird / human (Table 4). 
Table 1. Densities of Anopheles spp. larvae collected in breeding sites in the municipalities of Buriticupu and São José de Ribamar, Maranhão, State, from 2006 to 2011.

\begin{tabular}{|c|c|c|c|c|c|c|}
\hline \multirow{2}{*}{ Species } & \multicolumn{2}{|c|}{ Buriticupu } & \multicolumn{2}{|c|}{ São José de Ribamar } & \multicolumn{2}{|c|}{ Total/Species } \\
\hline & $\mathrm{n}$ & $\%$ & $\mathrm{n}$ & $\%$ & $\mathbf{n}$ & $\%$ \\
\hline Anopheles albitarsis & 32 & 25.0 & 14 & 22.6 & 46 & 24.2 \\
\hline Anopheles aquasalis & 0 & 0,0 & 38 & 61.3 & 38 & 20.0 \\
\hline Anopheles darlingi & 78 & 60.9 & 0 & 0.0 & 78 & 41.1 \\
\hline Anopheles nuneztovari & 12 & 9.4 & 6 & 9.7 & 18 & 9.5 \\
\hline Anopheles oswaldoi & 6 & 4.7 & 4 & 6.5 & 10 & 5.3 \\
\hline Total/locality & 128 & - & 62 & - & 190 & - \\
\hline LIMH & 1.33 & - & 0.64 & - & 2.00 & - \\
\hline
\end{tabular}

$\mathrm{LIMH}=$ larvae index per man/hour.

Table 2. Densities of adult Anopheles spp. collected in three breeding sites of Buriticupu and São José de Ribamar municipalities, Maranhão State, from 2006 to 2011.

\begin{tabular}{|c|c|c|c|c|c|c|c|c|}
\hline \multirow{3}{*}{ Species } & \multicolumn{6}{|c|}{ Environment } & \multirow{2}{*}{\multicolumn{2}{|c|}{ Total/Species }} \\
\hline & \multicolumn{2}{|c|}{ Intradomicile } & \multicolumn{2}{|c|}{ Peridomicile } & \multicolumn{2}{|c|}{ Extradomicile } & & \\
\hline & $\mathbf{n}$ & $\%$ & $\mathbf{n}$ & $\%$ & $\mathbf{n}$ & $\%$ & $\mathbf{n}$ & $\%$ \\
\hline \multicolumn{9}{|l|}{ Buriticupu } \\
\hline Anopheles albitarsis & 156 & 26.17 & 348 & 21.27 & 149 & 24.31 & 653 & 22.95 \\
\hline Anopheles aquasalis & 4 & 0.67 & 13 & 0.79 & 0 & 0.00 & 17 & 0.60 \\
\hline Anopheles darlingi & 389 & 65.27 & 1,030 & 62.96 & 390 & 63.62 & 1,809 & 63.59 \\
\hline Anopheles evansae & 0 & 0.00 & 92 & 5.62 & 0 & 0.00 & 92 & 3.23 \\
\hline Anopheles galvaoi & 3 & 0.50 & 5 & 0.31 & 10 & 1.63 & 18 & 0.63 \\
\hline Anopheles nuneztovari & 5 & 0.84 & 41 & 2.51 & 26 & 4.24 & 72 & 2.53 \\
\hline Anopheles oswaldoi & 39 & 6.54 & 85 & 5.20 & 37 & 6.04 & 161 & 5.66 \\
\hline Anopheles strodei & 0 & 0.00 & 12 & 0.73 & 1 & 0.16 & 13 & 0.46 \\
\hline Anopheles triannulatus & 0 & 0.00 & 10 & 0.61 & 0 & 0.00 & 10 & 0.35 \\
\hline Total/environment & 596 & - & 1,636 & - & 613 & - & 2,845 & - \\
\hline \multicolumn{9}{|l|}{ São José de Ribamar } \\
\hline Anopheles albitarsis & 1 & 25.00 & 22 & 30.99 & ns & - & 23 & 30.67 \\
\hline Anopheles aquasalis & 2 & 50.00 & 33 & 46.48 & ns & - & 35 & 46.67 \\
\hline Anopheles darlingi & 1 & 25.00 & 4 & 5.63 & ns & - & 5 & 6.67 \\
\hline Anopheles oswaldoi & 0 & 0.00 & 9 & 12.68 & ns & - & 9 & 12.00 \\
\hline Anopheles nuneztovari & 0 & 0.00 & 3 & 4.23 & ns & - & 3 & 4.00 \\
\hline Total/environment & 4 & - & 71 & - & - & - & 75 & - \\
\hline Total & & & & & & & 2,920 & \\
\hline
\end{tabular}

ns = non-sampled environment

In São José de Ribamar, the precipitin tests revealed that 20 females (80.00\%) of $A$. aquasalis fed on human blood, being two intradomicile (8.00\%) and 18 (72\%) in peridomicile. The tests also revealed that five $(20 \%)$ females caught in peridomicile had fed on birds. Considering the results of the double precipitin reaction, only three $(20.00 \%)$ of the female caught in peridomicile revealed the combination of cat / human feeding and 12 specimens (80.00\%) also in peridomicile the human / bird combination (Table 4).

\section{Correlation between Anopheles species}

In Buriticupu, we detected that $A$. darlingi coexists positively in significance with $A$. albitarsis s.l., A. oswaldoi, A. nuneztovari and A. evansae in Buriticupu. However, A. albitarsis s.l. was dominant on the same species, with the exception of $A$. darlingi. The behavior of these species reveals the potential of $A$. darlingi as the main vector in the environment and $A$. albitarsis s.l. as an associated vector. In São José de Ribamar, the coexistence of the species was significant for $A$. aquasalis and $A$. albitarsis s.l., and between $A$. oswaldoi and $A$. nuneztovari. The species $A$. darlingi and $A$. albitarsis s.l. coexist in that locality in a positive way among the evaluated environments, in the same way as A. oswaldoi and A. nuneztovari (Table 5).

\section{Correlation between Anopheles species and climate variables}

Of all the climatic data analyzed, only rainfall showed a significant correlation with $A$. darlingi in Buriticupu and with A. albitarsis s.l. and A. aquasalis in São José de Ribamar (Table
6). During the period of this study, in both localities, the monthly variations of temperature and humidity had few differences in amplitudes. However, the rainfall regime was decisive for the maintenance of $A$. darlingi in Buriticupu ( $P=$ 0.0280 ) (Figure 1 ) and for $A$. aquasalis $(P=0.0051)$ (Figure 2 ) in São José de Ribamar. These data indicate that the presence of these species was strongly related to the rainy seasons in both localities.

\section{Peak of hematophagy}

The biting activity of the females in Buriticupu, behaved in a very similar way for the species A. darlingi, A. albitarsis s.l., A. nuneztovari and $A$. oswaldoi whose peaks occurred in the first two schedules in practically all of the evaluated environments. Anopheles darlingi reached 7.0 mosquito/man/hour index in intradomicile between 6:00 and 7:00 pm and 10.9 between 7:00 and 8:00 pm. In peridomicile at the same time, the rates of mosquito/man/hour were 14.4 and 42.1, respectively. Already in extradomicile, were 6.9 and 10.9 mosquito/man/ hour. For A. albitarsis s.l. the highest indexes were reached in peridomicile between 6:00 and 7:00 pm and from 7:00 to 8:00 pm respectively, 7.0 and 10.0 mosquito/man/hour. In the species $A$. nuneztovari and $A$. oswaldoi the indexes were lower than one (Figure 3 ). In São José de Ribamar, only mosquitoes were collected during 12-hour samplings in a peridomicile environment. The mosquito/man/hour indexes were considered very low, varying between 0,00 and 0,07 , in this case it wasn't possible to detect a well-defined period of the species' peak (Figure 4). 
Table 4. Results of the simple and double reaction of the precipitin for the analysis of the Anopheles darlingi and Anopheles aquasalis blood-feeding captured intradomicile, peridomicile and extradomicile environments in Buriticupu and São José de Ribamar municipalities, Maranhão State, from 2006 to 2011.

\begin{tabular}{|c|c|c|c|c|c|c|c|c|}
\hline \multirow[b]{2}{*}{$\begin{array}{c}\text { Feeding } \\
\text { source }\end{array}$} & \multicolumn{2}{|c|}{ Intradomicile } & \multicolumn{2}{|c|}{ Peridomicile } & \multicolumn{2}{|c|}{ Extradomicile } & \multicolumn{2}{|c|}{ Total } \\
\hline & $\begin{array}{c}\text { Anopheles } \\
\text { darlingi } \\
\text { n (\%) }\end{array}$ & $\begin{array}{c}\text { Anopheles } \\
\text { aquasalis } \\
\text { n (\%) }\end{array}$ & $\begin{array}{c}\text { Anopheles } \\
\text { darlingi } \\
\mathrm{n}(\%)\end{array}$ & $\begin{array}{c}\text { Anopheles } \\
\text { aquasalis } \\
\text { n (\%) }\end{array}$ & $\begin{array}{c}\text { Anopheles } \\
\text { darlingi } \\
\text { n (\%) }\end{array}$ & $\begin{array}{c}\text { Anopheles } \\
\text { aquasalis } \\
\text { n (\%) }\end{array}$ & $\begin{array}{c}\text { Anopheles } \\
\text { darlingi } \\
\text { n (\%) }\end{array}$ & $\begin{array}{c}\text { Anopheles } \\
\text { aquasalis } \\
\mathrm{n}(\%)\end{array}$ \\
\hline \multicolumn{9}{|c|}{ Buriticupu: simple reaction } \\
\hline Human & $27(7.73)$ & $2(11.76)$ & $50(14.32)$ & $10(58.82)$ & $43(12.32)$ & 0 & $120(34.38)$ & $12(70.58)$ \\
\hline Cattle & $10(2.86)$ & 0 & $23(6.59)$ & $2(11.76)$ & $23(6.59)$ & 0 & $56(16.04)$ & $2(11.76)$ \\
\hline Bird & $18(5.15)$ & $2(11.76)$ & $16(4.58)$ & 0 & $48(13.75)$ & 0 & $82(23.49)$ & $2(11.76)$ \\
\hline Rodent & $6(1.71)$ & 0 & $13(3.72)$ & 0 & $11(3.15)$ & 0 & $30(8.59)$ & 0 \\
\hline Skunk & 0 & 0 & 0 & 0 & $12(3.43)$ & 0 & $12(3.43)$ & 0 \\
\hline Dog & 0 & 0 & $35(10.02)$ & 0 & $5(1.43)$ & 0 & $40(11.46)$ & 0 \\
\hline Cat & 0 & 0 & 0 & $1(5.88)$ & 0 & 0 & 0 & $1(5.88)$ \\
\hline Not reacted & $3(0.85)$ & 0 & $2(0.57)$ & 0 & $4(1.14)$ & 0 & $9(2.57)$ & 0 \\
\hline Subtotal & $64(18.33)$ & $4(23.52)$ & $139(39.82)$ & $13(76.47)$ & $146(41.83)$ & 0 & 349 & 17 \\
\hline \multicolumn{9}{|c|}{ Buriticupu: double reaction } \\
\hline Bird/Human & $17(11.64)$ & $1(100.00)$ & $19(13.01)$ & 0 & 0 & 0 & $36(24.65)$ & $1(100.00)$ \\
\hline $\begin{array}{l}\text { Rodent/ } \\
\text { Human }\end{array}$ & $21(14.38)$ & 0 & 0 & 0 & 0 & 0 & $21(14.38)$ & 0 \\
\hline Human/Skunk & 0 & 0 & 0 & 0 & $20(13.69)$ & 0 & $20(13.69)$ & 0 \\
\hline Bird/Dog & 0 & 0 & 0 & 0 & $15(10.27)$ & 0 & $15(10.27)$ & 0 \\
\hline Skunk/Bird & 0 & 0 & $14(9.58)$ & 0 & $18(12.32)$ & 0 & $32(21.91)$ & 0 \\
\hline Bird/Cattle & 0 & 0 & $6(4.10)$ & 0 & $16(10.95)$ & 0 & $22(15,06)$ & 0 \\
\hline Subtotal & $38(26.02)$ & $1(100.00)$ & 39 (26.71) & 0 & $69(47.26)$ & 0 & 146 & 1 \\
\hline \multicolumn{9}{|c|}{ São José de Ribamar: simple reaction } \\
\hline Human & - & $2(8.00)$ & - & $18(72.00)$ & - & - & - & $20(80.00)$ \\
\hline Bird & - & 0 & - & $5(20.00)$ & - & - & - & $5(20.00)$ \\
\hline Subtotal & - & $2(8.00)$ & - & $23(92.00)$ & - & - & - & 25 \\
\hline \multicolumn{9}{|c|}{ São José de Ribamar: double reaction } \\
\hline Cat/Human & - & - & - & $3(20.00)$ & - & - & - & $3(20.00)$ \\
\hline Human/Bird & - & - & - & $12(80.00)$ & - & - & - & $12(80.00)$ \\
\hline Subtotal & - & - & - & $15(100.00)$ & - & - & - & 15 \\
\hline
\end{tabular}

\section{Natural infection by Plasmodium spp.}

The rates of natural infection could only be analyzed in Buriticupu, due to the more expressive volume of specimens captured. Only one pool was positive Plasmodium vivax and four for Plasmodium falciparum in Anopheles darlingi, whose MIR were respectively $0,6 \%$ and $2.2 \%$. Anopheles albitarsis s.l. positivized a pool for P. vivax and MIR of $1.1 \%$. Anopheles nuneztovari positivized for $P$. vivax and one for $P$. falciparum, whose MIR were $8.3 \%$ and $1.1 \%$. Anopheles oswaldoi was positive for $P$. falciparum and MIR 2.3\% and also presented positivity for mixed infection, MIR 2.3\% (Table 7). The analysis of the distribution of Anopheles spp. naturally infected by Plasmodium spp. guide us to the conclusion that $A$. darlingi was found infected in the three environments, ranging in the first four hours of the evening and closer to dawn. Anopheles albitarsis s.l. infected occurred in peridomicile and in extradomicile during the first two hours of the evening, respectively. Anopheles oswaldoi was found infected in intradomicile and peridomicile also, during the first two nocturnal times. Anopheles nuneztovari was found infected in the peridomicile between 10:00 and 11:00 pm (Figure 5).

\section{DISCUSSION}

The records of Anopheles species found in this study, were reported for the first time in Estado do Maranhão in DEANE et al. (1948) which accomplished Anopheles sp. fauna collects in different locations, from the Amazon region to the coastal strip of the Brazilian northeast, from 1939 to 1944. The data that we collected enabled to register the predominance of the species $A$. aquasalis, $A$. darlingi and $A$. albitarsis s.l., mainly on the island of São Luís, denoting a pattern of occurrence similar to that one found in this work.

The breeding sites of anophelines in Buriticupu and in São José de Ribamar present shading characteristics and a presence of aquatic plants similar to those described by Consolı \& LOUREnÇO-de-Oliveira (1994), Moutinho et al. (2011) and ForattinI (2002) for the immature forms of the species recorded here. It should be noted that these breeding sites are located very close to the peridomicile, being this a conditioning factor for the continuous presence of these vectors during the whole year (MoutinHo et al. 2011). The type of influence that the presence of aquatic plants along with the limnological conditions in the different kinds of breeding sites, exert on the survival and density of the larvae has been well discussed, since the species tolerate extreme ranges of variations in the biotic and abiotic conditions of these environments (PINAULT \& Hunter 2012; Soleimani-Ahmadi et al. 2014). Such conditions are essential for species commonly found in freshwater (SAVAge et al. 1990) as in the case of A. darlingi, A. albitarsis s.l., A. nuneztovari and $A$. oswaldoi; as for those which are tolerant to certain levels of salinity (SAVAGE et al. 1990) as A. aquasalis. The breeding sites of $A$. aquasalis, in particular, are influenced 
Table 5. Estimates of partial correlations between adult Anopheles spp. (coexistence) in Buriticupu and in São José de Ribamar municipalities, Maranhão State, from 2006 to 2011

\begin{tabular}{|c|c|c|c|c|c|}
\hline Location & Pairs of variables & r Simple & r Partial & Correlation & Likelihood \\
\hline \multirow{21}{*}{ Buriticupu } & Anopheles darlingi $x$ Anopheles albitarsis & 0,72 & 0,776 & $9.6873^{* *}$ & 0,00001 \\
\hline & Anopheles darlingi $x$ Anopheles oswaldoi & 0,17 & 0,295 & $2.4314^{*}$ & 1,7134 \\
\hline & Anopheles darlingi $x$ Anopheles strodei & 0 & $-0,0279$ & $-0.2201 \mathrm{~ns}$ & 82,131 \\
\hline & Anopheles darlingi x Anopheles nuneztovari & 0,21 & 0,3746 & $3.1814 * *$ & 0,2417 \\
\hline & Anopheles darlingi x Anopheles galvaoi & 0,07 & 0,0998 & $0.7898 \mathrm{~ns}$ & 56,1646 \\
\hline & Anopheles darlingi $x$ Anopheles evansae & 0,21 & 0,362 & $3.0576 * *$ & 0,3388 \\
\hline & Anopheles albitarsis $x$ Anopheles oswaldoi & $-0,02$ & $-0,2564$ & $-2.0889 *$ & 3,8655 \\
\hline & Anopheles albitarsis $x$ Anopheles strodei & 0,02 & 0,0388 & $0.3057 n s$ & 75,8651 \\
\hline & Anopheles albitarsis $x$ Anopheles nuneztovari & $-0,04$ & $-0,3264$ & $-2.7193^{* *}$ & 0,8291 \\
\hline & Anopheles albitarsis $x$ Anopheles galvaoi & $-0,03$ & $-0,1181$ & $-0.9365 n s$ & 64,4759 \\
\hline & Anopheles albitarsis $x$ Anopheles evansae & 0 & $-0,2684$ & $-2.1938 *$ & 3,0314 \\
\hline & Anopheles oswaldoi $x$ Anopheles strodei & $-0,08$ & $-0,023$ & $-0.1815 n s$ & 85,0987 \\
\hline & Anopheles oswaldoi x Anopheles nuneztovari & $-0,01$ & $-0,0967$ & $-0.765 n s$ & 54,6767 \\
\hline & Anopheles oswaldoi x Anopheles galvaoi & 0,07 & 0,0172 & $0.1357 n s$ & 88,7787 \\
\hline & Anopheles oswaldoi x Anopheles evansae & $-0,07$ & $-0,1797$ & $-1.4382 \mathrm{~ns}$ & 15,1545 \\
\hline & Anopheles strodei $x$ Anopheles nuneztovari & $-0,02$ & $-0,0351$ & $-0.2762 n s$ & 77,9814 \\
\hline & Anopheles strodei x Anopheles galvaoi & $-0,09$ & $-0,0937$ & $-0.7413 n s$ & 53,2293 \\
\hline & Anopheles strodei $x$ Anopheles evansae & 0,14 & 0,1341 & $1.0657 \mathrm{~ns}$ & 29,0937 \\
\hline & Anopheles nuneztovari x Anopheles galvaoi & $-0,07$ & $-0,1215$ & $-0.9641 \mathrm{~ns}$ & 65,9329 \\
\hline & Anopheles nuneztovari x Anopheles evansae & 0,01 & $-0,0696$ & $-0.549 n s$ & 59,1715 \\
\hline & Anopheles galvaoi x Anopheles evansae & 0,03 & 0,0134 & $0.1057 \mathrm{~ns}$ & 91,2711 \\
\hline \multirow{10}{*}{ São José de Ribamar } & Anopheles aquasalis $x$ Anopheles albitarsis & 0,94 & 0,9153 & $18.1843^{* *}$ & 0,00001 \\
\hline & Anopheles darlingi $x$ Anopheles aquasalis & 0,37 & $-0,0003$ & $-0.0024 n s$ & 99,3478 \\
\hline & Anopheles darlingi $x$ Anopheles oswaldoi & $-0,04$ & 0,0404 & $0.3237 n s$ & 74,5862 \\
\hline & Anopheles darlingi x Anopheles nuneztovari & $-0,02$ & $-0,0625$ & $-0.5013 n s$ & 62,3665 \\
\hline & Anopheles albitarsis $x$ Anopheles aquasalis & 0,42 & 0,0463 & $0.3709 n s$ & 71,2857 \\
\hline & Anopheles albitarsis $x$ Anopheles oswaldoi & $-0,05$ & $-0,0495$ & $-0.3968 n s$ & 69,4932 \\
\hline & Anopheles albitarsis $x$ Anopheles nuneztovari & 0 & 0,0587 & $0.4703 n s$ & 64,4675 \\
\hline & Anopheles aquasalis $x$ Anopheles oswaldoi & $-0,1$ & $-0,0515$ & $-0.4124 n s$ & 68,4191 \\
\hline & Anopheles aquasalis $x$ Anopheles nuneztovari & $-0,03$ & $-0,041$ & $-0.3283 n s$ & 74,2676 \\
\hline & Anopheles oswaldoi x Anopheles nuneztovari & 0,28 & 0,2929 & $2.4509 *$ & 1,6242 \\
\hline
\end{tabular}

*= significant result; ns= no significant.

by the cycles of tides and rivers that flow into the estuary of Arraial Bay, near Guarapiranga. As reported by MOSER et al. (2004) the immature habitats of this species correlated positively with the alkalinity and salinity of the water, typically of mangroves.

The physico-chemical characteristics of the breeding sites in both localities are similar to the data obtained by SAVAGE et al. (1990) in Chiapas, Mexico and with TADEl et al. (1993) in Amazonas, Brazil. The value of TDS² found, was lower than the findings of CLABORN et al. (2002) in South Korea. As for the nitrite, nitrate, ammonia and phosphorus values, the records of Mwangangl et al. (2007) report that Anopheles arabiensis Patton in flooded rice plantations, in Kenya, are tolerant to different levels of this chemical compound. The LIMHs were compatible with those obtained in the controls of RODRIGUEs et al. (2008) and lower than the controls of FerReIRA et al. (2015) in artificial breeding sites, such as potholes and pisciculture tanks, respectively.

The results enabled to verify that the anophelines fauna among home environments was more frequent in peridomicile. In this environment are located people at dusk and in the early hours of the night, as well as domestic animals and some occasional wild ones. In this context, it becomes possible to know the anophelines fauna, allowing to assess the level of risk of malaria transmission. Considering the densities of the vectors, the data found in Buriticupu, were more expressive than those obtained in the following municipalities: Paço do Lumiar (199 specimens), São Luiz (2,132 specimens), Raposa $(1,215)$ and São José de Ribamar (229 specimens) by Rebêto et al. (2007). The most plausible explanation for the presence of these species is the geographic position of Maranhão, which is located in the semi-humid transition zone between hot and humid climate with predominance of ombrophilous forest and semi-arid with drier vegetation. However, in São José de Ribamar, the register of the species was low, 75 in total, when comparing the works of ReBÊLo et al. (2007) carried out in the same locality. Nevertheless, our data corroborate those obtained in the state, both in Buriticupu and in the island of São Luis (ReBÊLo et al. 2007; SILVA et al. 2006).

Anopheles darlingi presented a positive correlation with four vectors $A$. albitarsis s.l., A. oswaldoi, A. nuneztovari and $A$. evansae and from $A$. albitarsis s.l. with a positive correlation with $A$. evanse and negative with $A$. nuneztovari and $A$. oswaldoi in Buriticupu. ReBÊLo et al. (2007) reported the coexistences in the municipality, especially in periods of malaria transmissions. Positive correlations between $A$. aquasalis and A. albitarsis s.l. and A. oswaldoi and A. nuneztovari were also obtained; these findings are corroborated by SiLva et al. (2006) and RebÊLo et al. (2007) for São José de Ribamar. The rainy season was a condition for the maintenance of $A$. darlingi, $A$. albitarsis s.l. and A. aquasalis in both locations. GALARDo et al. (2009) found a significant correlation between $A$. darlingi and the rainy season. Other reports have shown relevant densities for these vectors in Amazonian regions wettest periods (TADEI et al. 1998; Moutinho et al. 2011; Barbosa et al. 2014) and the island of São Luiz (XAVIER \& Rebêto 1999). In the rainy season, the availability of natural breeding sites increases, providing new breeding sites for anophelines, a hegemonic factor for expanding the densities of these mosquitoes.

Anopheles darlingi was the species that presented the greatest endophilic behavior, revealing the ability that this mosquito has to make the blood-feeding or hematophagy on humans 
Table 6. Estimates of partial correlations between adult Anopheles species and climate variables in Buriticupu and in São José de Ribamar municipalities, Maranhão State, from 2006 to 2011.

\begin{tabular}{|c|c|c|c|c|c|}
\hline Location & Pairs of variables & r Simple & r Partial & Correlation & Likelihood \\
\hline \multirow{21}{*}{ Buriticupu } & Temperature $\mathrm{x}$ Anopheles darlingi & $-0,06$ & 0,0001 & $0.0008 \mathrm{~ns}$ & 99,4708 \\
\hline & Temperature $\times$ Anopheles albitarsis & $-0,09$ & $-0,0479$ & $-0.3778 n s$ & 70,8115 \\
\hline & Temperature $x$ Anopheles oswaldoi & $-0,04$ & $-0,0491$ & $-0.3867 n s$ & 70,1942 \\
\hline & Temperature $\mathrm{x}$ Anopheles strodei & 0,14 & 0,1494 & $1.1897 n s$ & 23,6966 \\
\hline & Temperature $\mathrm{x}$ Anopheles nuneztovari & $-0,1$ & $-0,0334$ & $-0.2634 n s$ & 78,9111 \\
\hline & Temperature $\mathrm{x}$ Anopheles galvaoi & 0,01 & 0,0358 & $0.2818 \mathrm{~ns}$ & 77,5759 \\
\hline & Temperature $x$ Anopheles evansae & 0,27 & 0,1753 & $1.4023 \mathrm{~ns}$ & 16,2118 \\
\hline & Rain x Anopheles darlingi & 0,34 & 0,2723 & $2.2282^{*}$ & 2,7958 \\
\hline & Rain $x$ Anopheles albitarsis & 0,19 & $-0,088$ & $-0.6955 n s$ & 50,37 \\
\hline & Rain $x$ Anopheles oswaldoi & 0,17 & 0,0713 & $0.5629 \mathrm{~ns}$ & 58,2459 \\
\hline & Rain $\times$ Anopheles strodei & $-0,07$ & $-0,0437$ & $-0.3443 n s$ & 73,1444 \\
\hline & Rain $x$ Anopheles nuneztovari & $-0,02$ & $-0,1015$ & $-0.8033 n s$ & 56,9712 \\
\hline & Rain x Anopheles galvaoi & 0,16 & 0,119 & $0.9434 \mathrm{~ns}$ & 64,8407 \\
\hline & Rain $x$ Anopheles evansae & 0,04 & $-0,0511$ & $-0.4031 \mathrm{~ns}$ & 69,0654 \\
\hline & Relative humidity $\times$ Anopheles darlingi & 0,1 & 0,1088 & $0.8616 n s$ & 60,3463 \\
\hline & Relative humidity $\times$ Anopheles albitarsis & 0,07 & $-0,05$ & $-0.3943 n s$ & 69,6746 \\
\hline & Relative humidity $\times$ Anopheles oswaldoi & $-0,09$ & $-0,1395$ & $-1.1089 n s$ & 27,1245 \\
\hline & Relative humidity $x$ Anopheles strodei & 0,08 & 0,1623 & $1.2951 \mathrm{~ns}$ & 19,7148 \\
\hline & Relative humidity $x$ Anopheles nuneztovari & 0,21 & 0,1512 & $1.2047 n s$ & 23,0956 \\
\hline & Relative humidity x Anopheles galvaoi & 0,05 & 0,0924 & $0.731 \mathrm{~ns}$ & 52,5915 \\
\hline & Relative humidity $x$ Anopheles evansae & $-0,21$ & $-0,1947$ & $-1.5628 n s$ & 11,91 \\
\hline \multirow{15}{*}{ São José de Ribamar } & Temperature $\mathrm{x}$ Anopheles darlingi & $-0,1$ & 0,0165 & $0.1318 \mathrm{~ns}$ & 89,0997 \\
\hline & Temperature $\times$ Anopheles albitarsis & $-0,1$ & $-0,0707$ & $-0.567 n s$ & 57,9678 \\
\hline & Temperature $\times$ Anopheles aquasalis & $-0,11$ & $-0,1713$ & $-1.3907 n s$ & 16,5481 \\
\hline & Temperature $x$ Anopheles oswaldoi & 0,01 & 0,0018 & $0.0144 \mathrm{~ns}$ & 98,5492 \\
\hline & Temperature $\mathrm{x}$ Anopheles nuneztovari & 0,08 & 0,0481 & $0.3854 \mathrm{~ns}$ & 70,2813 \\
\hline & Rain $\times$ Anopheles darlingi & 0,55 & $-0,2206$ & $-1.8094 n s$ & 7,1587 \\
\hline & Rain x Anopheles albitarsis & 0,65 & 0,4257 & $3.7632 * *$ & 0,0456 \\
\hline & Rain $\mathrm{x}$ Anopheles aquasalis & 0,51 & 0,3409 & $2.9005 * *$ & 0,5117 \\
\hline & Rain $\times$ Anopheles oswaldoi & $-0,03$ & 0,035 & $0.2805 n s$ & 77,6724 \\
\hline & Rain $\times$ Anopheles nuneztovari & 0,03 & 0,0165 & $0.1316 n s$ & 89,1131 \\
\hline & Relative humidity $\times$ Anopheles darlingi & $-0,05$ & $-0,0173$ & $-0.1387 n s$ & 88,5285 \\
\hline & Relative humidity $\mathrm{x}$ Anopheles albitarsis & $-0,06$ & 0,0287 & $0.2299 \mathrm{~ns}$ & 81,3889 \\
\hline & Relative humidity $\mathrm{x}$ Anopheles aquasalis & $-0,23$ & $-0,2221$ & $-1.8227 n s$ & 6,9585 \\
\hline & Relative humidity $\times$ Anopheles oswaldoi & 0,13 & 0,1442 & $1.1662 \mathrm{~ns}$ & 24,6475 \\
\hline & Relative humidity $x$ Anopheles nuneztovari & $-0,09$ & $-0,1232$ & $-0.9936 n s$ & 67,4717 \\
\hline
\end{tabular}

*= significant result; ns= no significant.

Table 7. Minimum infection rate for natural infections of Plasmodium ssp. in four species of Anopheles captured in Buriticupu, Maranhão, State, 2006 a 2011.

\begin{tabular}{lcccccccc}
\hline \multirow{2}{*}{ Species } & $\mathbf{n}$ & Pools $\mathbf{c}$ & \multicolumn{2}{c}{ Plasmodium vivax } & \multicolumn{2}{c}{ Plasmodium falciparum } & \multicolumn{2}{c}{ P. vivax + P. falciparum } \\
\cline { 5 - 9 } & & species & Positive Pools & MIR \% & Positive Pools & MIR \% & Positive Pools & MIR \% \\
\hline Anopheles albitarsis & 238 & 90 & 1 & 1.1 & 1 & 1.1 & 0 & 0 \\
Anopheles darlingi & 804 & 178 & 1 & 0.6 & 4 & 2.2 & 0 & 0 \\
Anopheles nuneztovari & 19 & 12 & 1 & 8.3 & 1 & 1.1 & 0 & 0 \\
Anopheles oswaldoi & 238 & 44 & 0 & 0 & 1 & 2.3 & 1 & 2.3 \\
\hline \multicolumn{1}{c}{ Total } & $\mathbf{1 , 2 9 9}$ & $\mathbf{3 2 4}$ & $\mathbf{3}$ & - & $\mathbf{7}$ & - & $\mathbf{1}$ \\
\hline
\end{tabular}

MIR = Minimum infection rate.

inside the houses. In addition, it was also the most frequent in peridomicile and extradomicile. The first scottophase schedules were the ones with the highest mosquito/man/ hour indexes with a strong trend of bimodal behavior in Buriticupu. These behaviors were similar to those observed in works carried out in other locations in the Amazon (DEANE 1986; LOURENÇO-DE-OliveIRA et al. 1989; TADEI et al. 1993; TADEI et al. 2000; TADEl et al. 2017). Nevertheless, the biting activity of $A$. aquasalis during nighttime intervals was also reported in peridomicile (XAVIER \& ReBÊLo 1999). In general, mosquito/ man/hour indexes of the vectors differ greatly in each region, at certain times and between species (LOURENÇO-DE-OliveIRA et al. 1989; Galardo et al. 2009; PóvoA et al. 2009; Barbosa et al. 2016). Whereas the peridomicile was the most affluent and abundant species occurrence environment, allied to human habits in the main peak times of mosquitoes, this information points to guidance of differentiated control measures in this mean, since it has an important role in malaria transmission (Vezenegho et al. 2016).

It should be noted that in São José de Ribamar, five specimens of $A$. darlingi were found. The record of $A$. darlingi in the island of São Luís had been made by DeANE et al. (1948) in which they stated: "In an experiment done in 1941, freshly hatched larvae of A. darlingi captured in São Luiz (Maranhão)" [...]. The data of this work corroborate this affirmation because since that publication, no record of the species had been done in that island. Another important fact was the first record of $A$. aquasalis in Buriticupu; $300 \mathrm{~km}$ distant from the Atlantic coast (BARROs et al. 2015). 


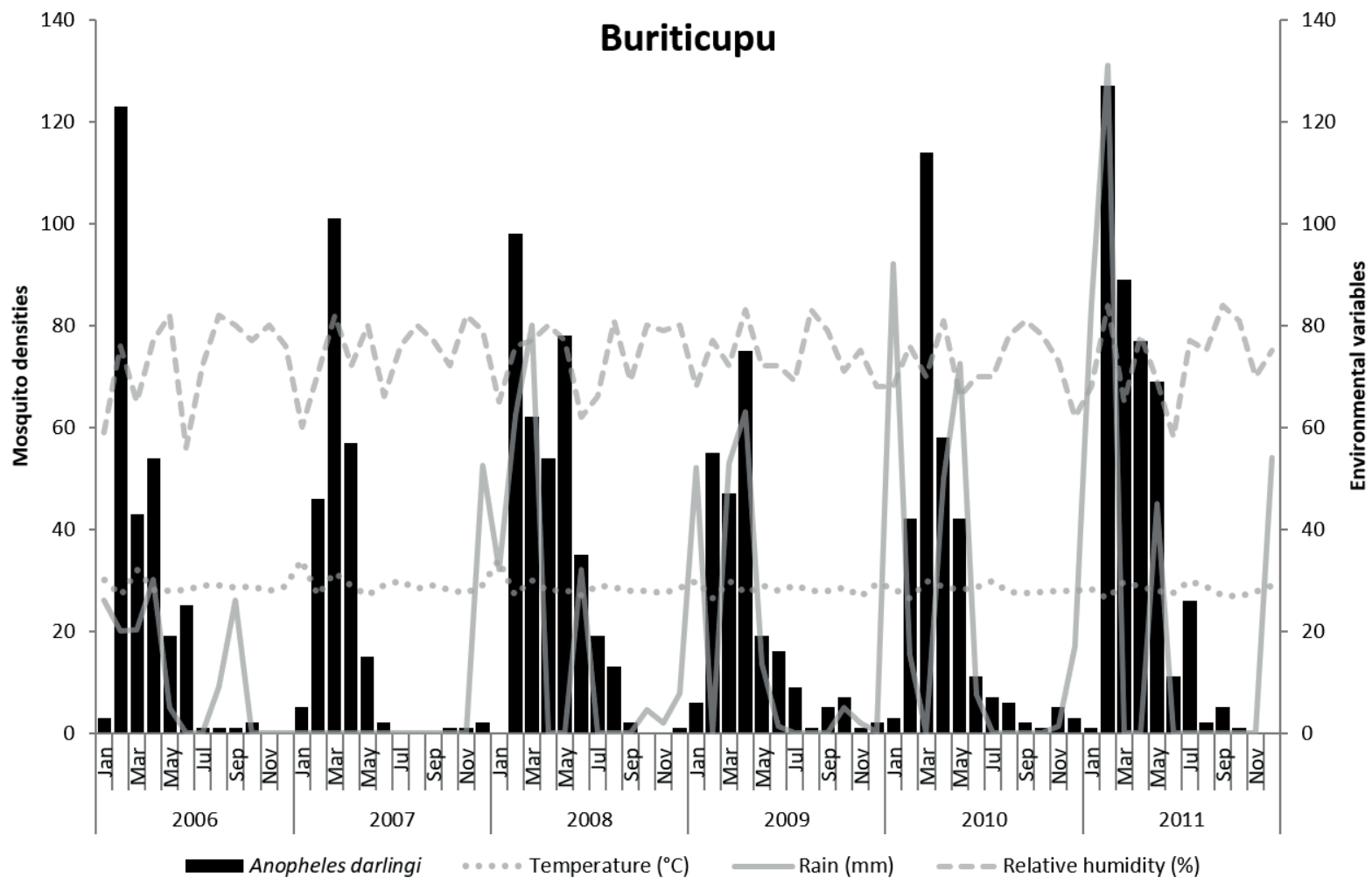

Figure 1. Densities of Anopheles darlingi mosquitoes and temperature averages, rainfall and relative humidity in Buriticupu, Maranhão State, from 2006 to 2011.

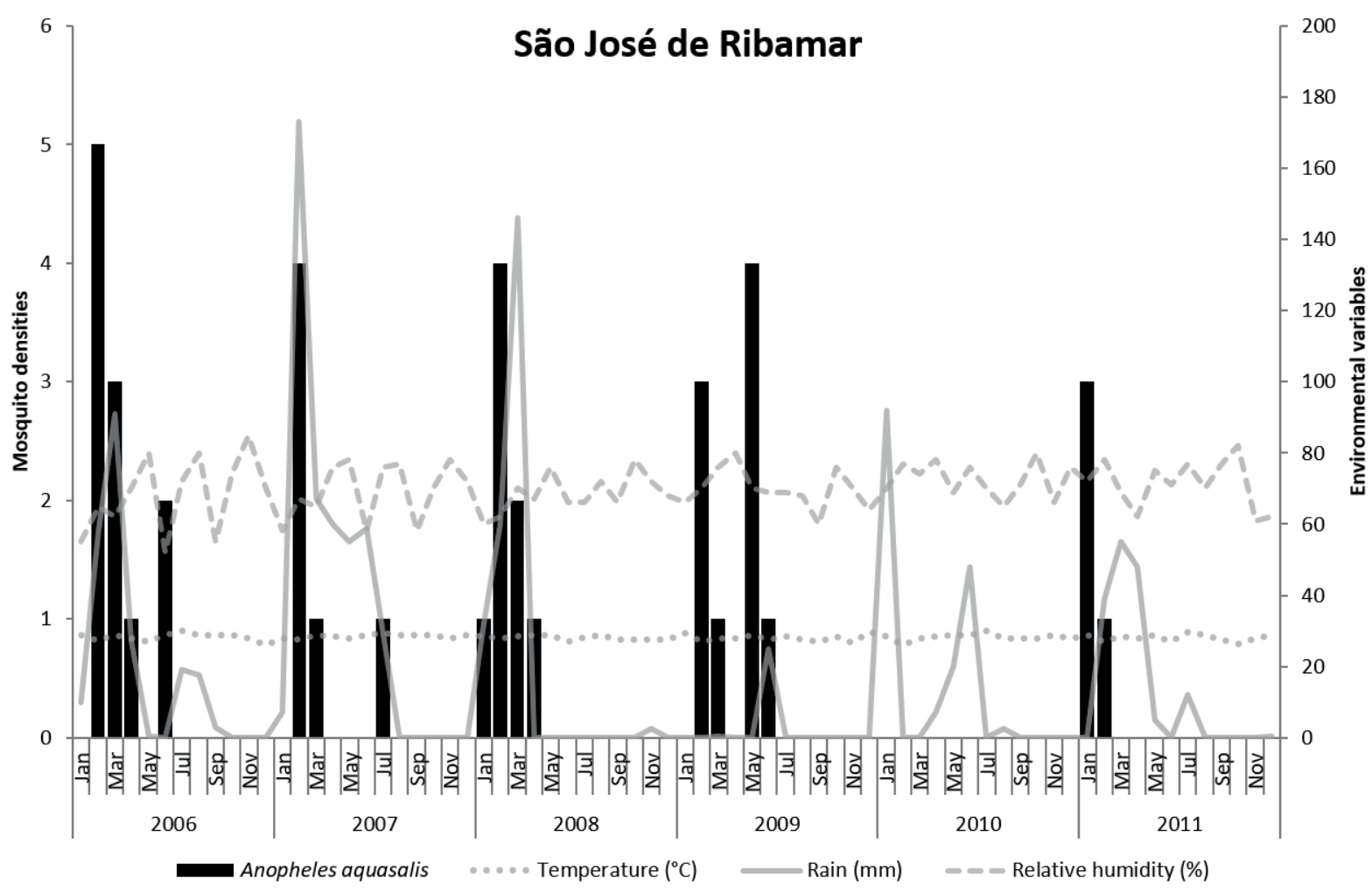

Figure 2. Densities of Anopheles aquasalis mosquitoes and temperature averages, rainfall and relative humidity in São José de Ribamar, Maranhão State, from 2006 to 2011.

The blood feeding of the two main vectors, $A$. darlingi and $A$. aquasalis allow to infer that they are very eclectic species feeding on several hosts. However, the higher frequencies of the reactions revealed that both presented a remarkable anthropophilic behavior, as observed in the experiments conducted by DeANe et al. (1949). In São José de Ribamar, samplings proved the preference of $A$. aquasalis to feed on humans (80\%). At this location the other animals hosts were birds and cats. This data differs from what was found by Flores-Mendoza et al. (1996), in Rio de Janeiro, who emphasized that this species exhibits zoophilic behavior. However, DEANE (1986), points out that the vector capacity of this species is related to the density of the population, whose effects are more pronounced in the north and northeast coast of Brazil.

The natural infection detected four species infected with Plasmodium ssp. in Buriticupu - A. darlingi, A. albitarsis s.l., A. oswaldoi and $A$. nuneztovari. Notoriously, $A$. darlingi, stands out being infected with both $P$. vivax and $P$. falciparum in the three environments analyzed, reason why it is considered the 

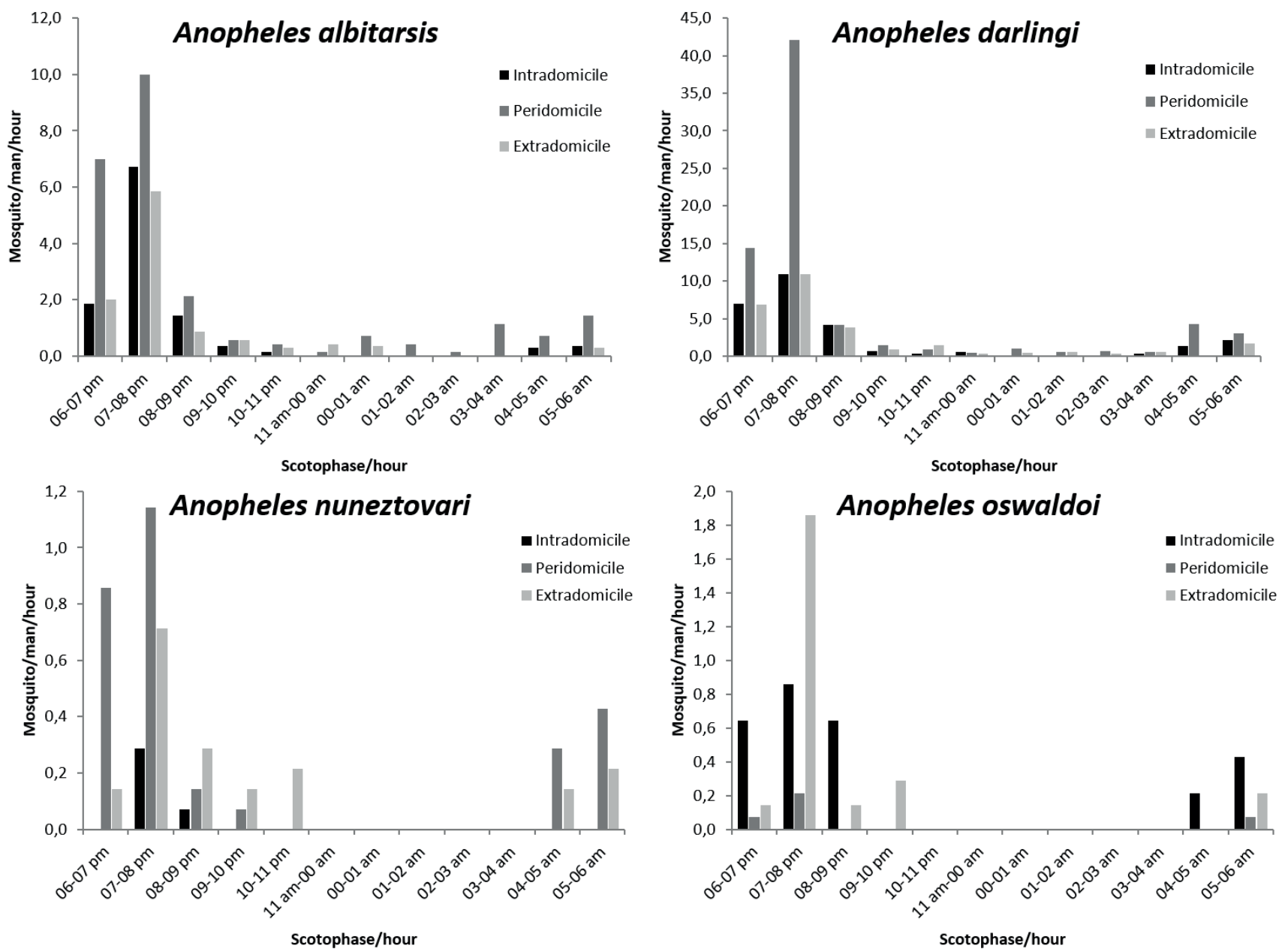

Figure 3. Mosquito / man / hour indexes for Anopheles spp. collected in three enviroments and activity schedules in Buriticupu, Maranhão State, from 2006 to 2011.

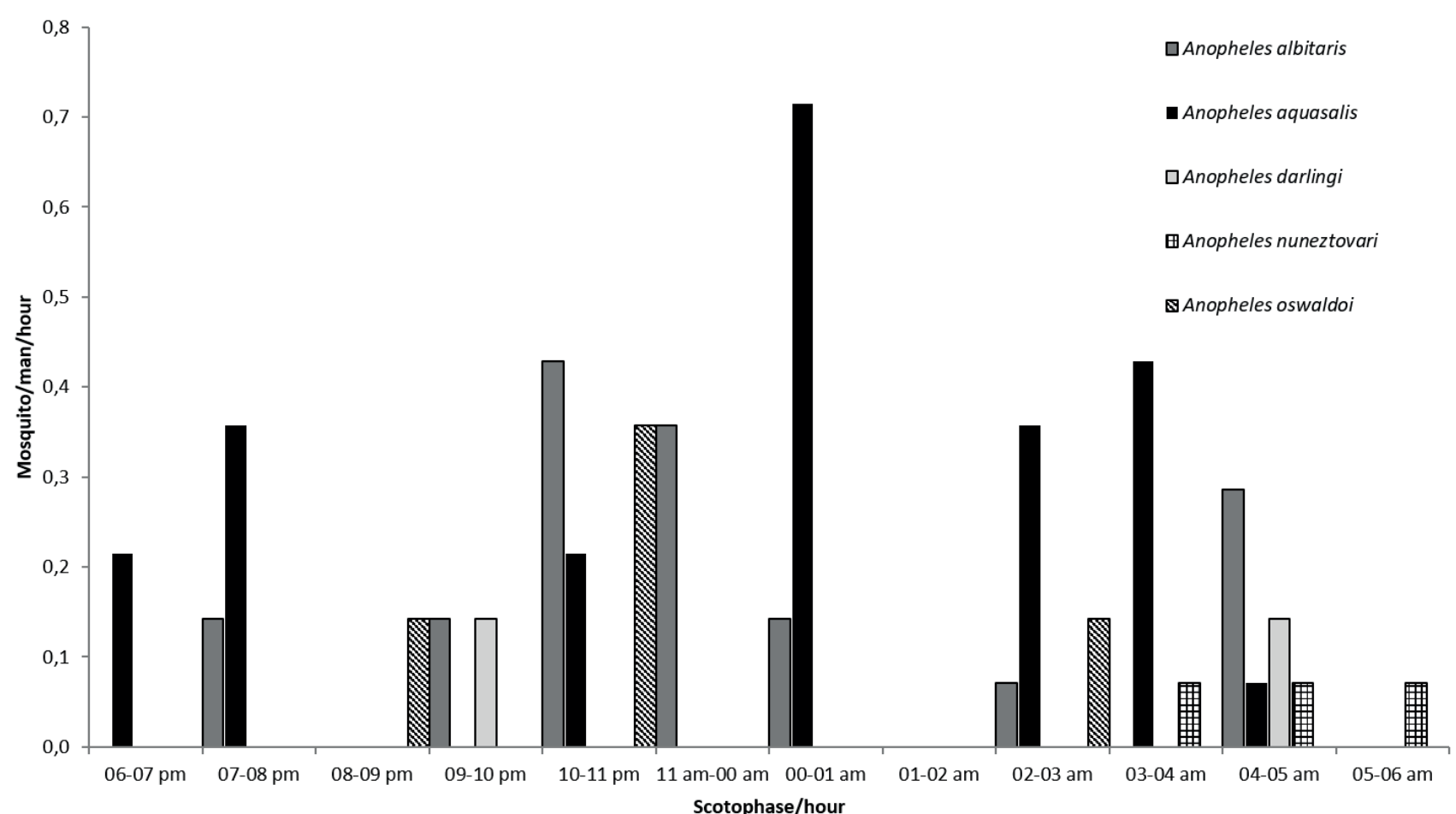

Figure 4. Mosquito / man / hour indexes for species of Anopheles collected in a peridomicile environment and activity schedules in São José de Ribamar, Maranhão State, from 2006 to 2011.

main vector of malaria in the region (TADEI et al. 1988; TADEI \& Dutary-Thatcher 2000; Hiwat \& Bretas 2011; Pimenta et al. 2015). Although infection rates have been low, this doesn't mean that the risk of transmission in the area is lower, since low parasitemias can trigger successive cycles of epidemics (KLEIN et al. 1991; Alves et al. 2005).
In the present study, the three main vectors of malaria in Brazil were detected in the evaluated areas: $A$. darlingi, $A$. aquasalis and $A$. albitarsis S.l., whose densities justify their dominance in the environment. Secondary vectors, such as, $A$. nuneztovari and $A$. oswaldoi were also found, however, in a smallest proportion. Nevertheless, as a whole, except for 


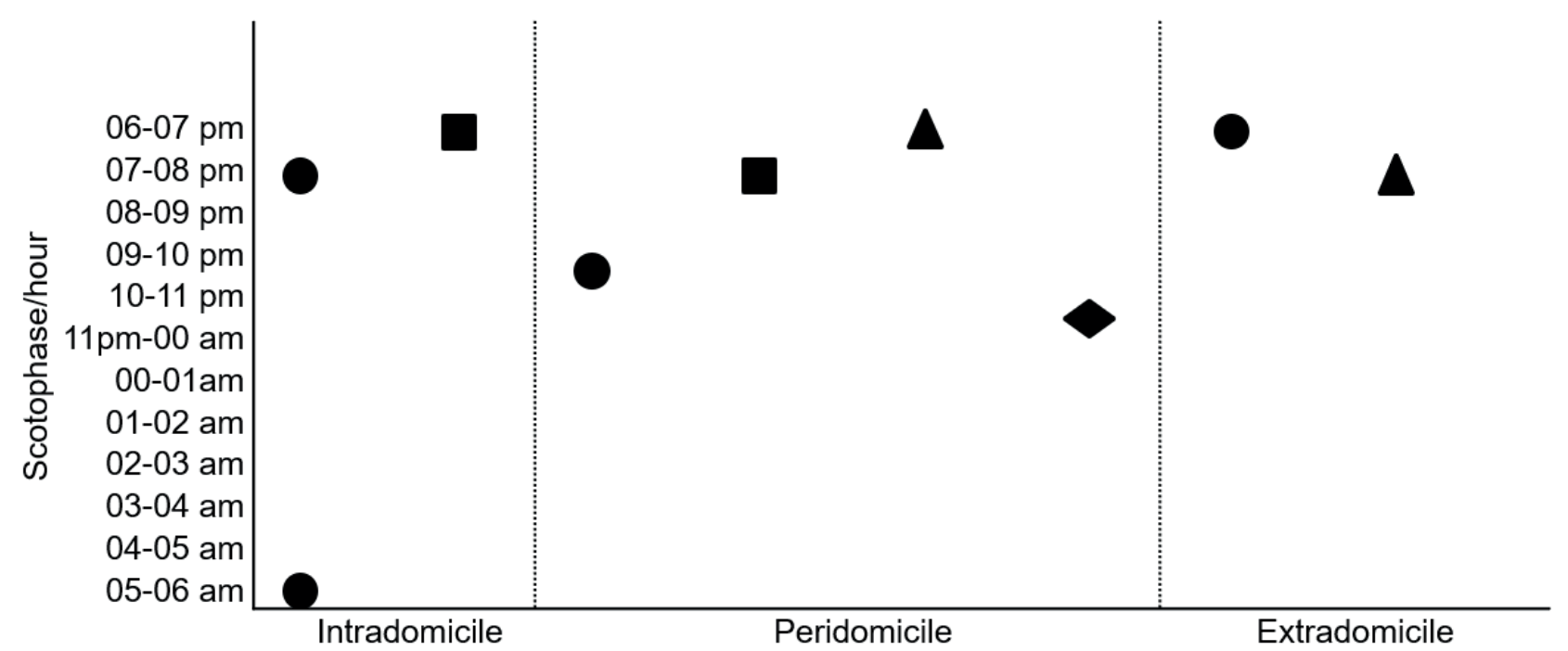

$\triangle$ Anopheles albitarsis Anopheles darlingi

Anopheles nuneztovari

Anopheles oswaldoi

Figure 4. Distribution of the natural infectivity of Plasmodium ssp. in Anopheles ssp. by schedule and environment in Buriticupu municipality, Maranhão State, from 2006 to 2011.

A. aquasalis, all of them had natural infections by Plasmodium ssp. Therefore, have a relevant role in the transmission of malaria, in the municipalities of Maranhão. The volume of information collected allows us to state that Anopheles darlingi remains as the main vector of malaria in Buriticupu. As $A$. aquasalis probably has important highlight in the transmission of the disease in São José de Ribamar.

Thus, both locations a high risk for malaria transmission. Finally, the data collected by this work contribute to elucidate a part of the transmission chain in both localities, as well as, serve to guide the control actions by the public health service and the population in general, so that they can adopt conduits to prevent new infections.

In addition, these data are important because they also contribute to the process of controlling and eliminating malaria, an activity which is relevant today, in the Amazon region. The areas of occurrence records of the species of Anopheles are the references for the implementation of specific actions, whose ultimate goal is the elimination of this disease, initially focusing on the $P$. falciparum (SANTELl et al. 2016).

\section{REFERENCES}

Alves, FP, LHS Gil, MT Marrelli, PEM Ribolla, EP Camargo \& LHP Silva, 2005. Asymptomatic Carriers of Plasmodium spp. as Infection Source for Malaria Vector Mosquitoes in the Brazilian Amazon. Journal of the Medical Entomology, 42: 777-779. DOI: https://doi.org/10.1093/jmedent/42.5.777

Barbosa, LMC, RNP Souto, RMA Ferreira \& VM Scarpassa, 2014. Composition, abundance and aspects of temporal variation in the distribution of Anopheles species in an area of Eastern Amazonia. Revista da Sociedade Brasileira de Medicina Tropical, 47: 313-320. DOI: https://doi.org/10.1590/0037-8682-0239-2013

Barbosa, LMC, RNP Souto, RMA Ferreira \& VM Scarpassa, 2016. Behavioral patterns, parity rate and natural infection analysis in anopheline species involved in the transmission of malaria in the northeastern Brazilian Amazon region. Acta Tropica, 164: 216-225. DOI: https://doi.org/10.1016/j. actatropica.2016.09.018

Barros, VLL, FM Costa, AR Silva, EGR Gonçalves \& WP Tadei, 2015. First record of Anopheles aquasalis associated with malaria transmission in a community in Buriticupu municipality, Maranhão state, Brasil. Journal of Research in Biology, 5: 1782-1787.

Claborn, DM, PB Hshieh, DR Roberts, TA Klein, BC Zeichner \& RG Andre, 2002. Environmental factors associated with larval habitats of malaria vectors in northern Kyunggi Province, Republic of Korea. Journal of the American Mosquito Control Association, 18: 178-185.

Consoli, RAGB \& R Lourenço-de-Oliveira, 1994. Principais Mosquitos de Importância Sanitária no Brasil. 1st ed. Rio de Janeiro: Fundação Oswaldo Cruz. 228 p.

Davis, NC, 1931. A Note on the Malaria-Carrying Anophelines in Belém, Para, and in Natal, Rio Grande do Norte, Brazil. Revista de Malariologia, 10: 43-51.

Deane, LM, 1986. Malaria vectors in Brazil. Memórias do Instituto Oswaldo Cruz, 81: 5-14. DOI: https://doi.org/10.1590/S0074-02761986000600002

Deane, LM, CS Vernin \& RG Damasceno, 1949. Avaliação das preferências alimentares das fêmeas de Anopheles darlingi e Anopheles aquasalis em Belém, Pará, por meio de Provas de preciptina, Revista do Serviço Especial de Saúde Pública. 2: 793-808.

Deane, LM, OR Causey \& MP Deane, 1948. Notes on the biology of Anopheles and northeastern regions of Brazil's Amazon. Revista do Serviço Especial de Saúde Publica,1: 827-965.

Ferreira, FA, AN Arcos, RTM Sampaio, IB Rodrigues \& WP Tadei, 2015. Effect of Bacillus sphaeriscus Neide on Anopheles (Diptera: Culicidae) and associated insect fauna in fish ponds in the Amazon. Revista Brasileira de Entomologia, 59: 234-239. DOI: https://doi.org/10.1016/j. rbe.2015.03.013

Flores-Mendoza, C, RA Cunha, DS Rocha \& R Lourenço-deOliveira, 1996. Determinação das fontes alimentares de Anopheles aquasalis (Diptera: Culicidae) no Estado do Rio de Janeiro, Brasil, pelo teste de precipitina. Revista de Saúde Pública, 30: 129-134. DOI: https://doi.org/10.1590/ S0034-89101996000200003

Forattini, OP, 2002. Culicidologia Médica. 1st ed. São Paulo: Edusp, $864 \mathrm{p}$.

Galardo, AKR, RH Zimmerman, LP Lounibos, LJ Young, CD Galardo, M Arruda \& CAA D'Almeida, 2009. Seasonal abundance of anopheline mosquitoes and their association with rainfall and malaria along the Matapi River, Amapá Brazil. Medical and Veterinary Entomology, 23: 335-349. DOI: https://doi.org/10.1111/j.13652915.2009.00839.x

Galvão, ALA, R Damasceno \& A Marques, 1942. Algumas observações sobre a biologia dos anofelinos de 
importância epidemiológica em Belém do Pará. Arquivos de Higiene e Saúde Publica, 12: 51-110.

Hiwat, H \& G Bretas, 2011. Ecology of Anopheles darlingi Root with respect to vector importance: a review. Parasites and Vectors, 4: 1-13. DOI: https://doi.org/10.1186/1756-33054-177

IPEA - Instituto de Pesquisa Econômica Aplicada, 2019. Radar IDHM: evolução do IDHM e de seus índices componentes no período de 2012 a 2017. Brasília: IPEA/ PNUD/FJP. 65 p.

Klein, TA, JB Lima, MS Tada \& R Miller, 1991. Comparative susceptibility of anopheline mosquitoes in Rondônia Brazil, to infection by Plasmodium vivax. American Journal of Tropical Medicine and Hygiene, 45: 463-470. DOI: https://doi.org/10.4269/ajtmh.1991.45.463

Lorosa, ES, RE Andrade, MGA Serra, JMM Rebelo \& MC Vinhaes, 1998. Estudo das fontes alimentares através da reação de precipitina e grau de infectividade em Triatoma rubrofasciata (De Geer, 1773) coletados na Ilha de São Luiz, Maranhão. Entomología y Vectores, 5: 241-250.

Lourenço-de-Oliveira, R, AG Guimarães, M Arlé, TF Silva, MG Castro, MA Motta \& LM Deane, 1989. Anopheline species, some of their habits and relation to malaria in endemic areas of Rondônia state, Amazon region of Brazil. Memórias do Instituto Oswaldo Cruz, 84: 501-514. DOI: https://doi.org/10.1590/S0074-02761989000400008

Moser, JB, A Gutiérrez \& RH Zimmerman, 2004. Relaciones entre tipos de hábitat, algunas variables químicas y la presencia de larvas de Anopheles aquasalis Curry y Anopheles pseudopunctipennis Theobald en una área costera del Estado Sucre, Venezuela. Entomotropica, 19: 79-84.

Moutinho, PR, LHS Gil, RB Cruz \& PEM Ribolla, 2011. Population dynamics, structure and behavior of Anopheles darlingi in a rural settlement in the Amazon rainforest of Acre, Brazil. Malaria Journal, 10: 1-12 DOI: https://doi. org/10.1186/1475-2875-10-174

Mwangangi, JM, EJ Muturi, JI Shililu, S Muriu, B Jacob, E W Kabiru, CM Mbogo, JI Githure \& RJ Novak, 2007. Environmental covariates of Anopheles arabiensis in a rice agroecosystem in mwea, central Kenya. Journal of the American Mosquito Control Association, 23: 371-377. DOI: https://doi.org/10.2987/5605.1

Pimenta, PF, AS Orfano, AC Bahia, AP Duarte, CM RíosVelásquez, FF Melo, FA Pessoa, GA Oliveira, KM Campos, LM Villegas, NB Rodrigues, R Nacif-Pimenta, RC Simões, WM Monteiro, R Amino, YM Traub-Cseko, JB Lima, MG Barbosa \& MV Lacerda, 2015. An overview of malaria transmission from the perspective of Amazon Anopheles vectors. Memórias do Instituto Oswaldo Cruz, 110: 23-47. DOI: https://doi.org/10.1590/0074-02760140266

Pinault LL \& FF Hunter, 2012. Characterization of larval habitats of Anopheles albimanus, Anopheles pseudopunctipennis, Anopheles punctimacula, and Anopheles oswaldoi s.l. populations in lowland and highland Ecuador. Journal of Vector Ecology. 37: 124-136. DOI: https://doi.org/10.1111/ j.1948-7134.2012.00209.x

Póvoa, MM, IMC Sucupira, GMR Viana, RNL Lacerda, RTL Lacerda, EPS Rosa, DG Primo, JÉA Araújo, JMS Nascimento, JMV Peres \& EL Carmo, 2009. Risco de transmissão de malária humana em área de Implantação de projeto de prospecção mineral, município d Juruti, Estado do Pará. Revista de Patologia Tropical, 38: 93-102. DOI: https://doi.org/10.5216/rpt.v38i2.6607

Póvoa, MM, JE Conn, CD Schlichting, JC Amaral, MN Segura, AN Silva, CC Santos, RN Lacerda, RT Souza \& D Galiza, 2003. Malaria vectors, epidemiology and the reemergence of Anopheles darlingi in Belém, Pará, Brazil. Journal of the Medical Entomology, 40: 379-386. DOI: https://doi.org/10.1603/0022-2585-40.4.379

R Development Core Team, 2013. R: A language and environment for statistical computing. Vienna: The $R$
Foundation for Statistical Computing. 63 p. Available on: $<$ http://www.R-project.org>.

Rebêlo, JMM, JLP Moraes, GA Alves, FS Leonardo, RV Rocha, WA Mendes, E Costa, LEMB Câmara, MJA Silva, YNO Pereira \& JAC Mendonça, 2007. Distribuição das espécies do gênero Anopheles (Diptera, Culicidae) no Estado do Maranhão, Brasil. Cadernos de Saúde Pública, 23: 2959-2971. DOI: https://doi.org/10.1590/S0102-311X2007001200017

Rodrigues, IB, WP Tadei, RLC Santos, S Santos \& JB Baggio. 2008. Controle da malária: eficácia de formulados de Bacillus sphaericus 2362 contra larvas de espécies de Anopheles em criadouros artificiais-tanques de piscicultura e criadouros de olaria. Revista de Patologia Tropical, 37: 161-176. DOI: https://doi.org/10.5216/rpt. v37i2.5047

Santelli, ACFS, CP Damasceno, CL Peterka \& PB Marchesini, 2016. Plano de eliminação de malária no Brasil, Fase 1: malária falciparum. Brasília: Ministério da Saúde. 37 p. Available on: <http://portalarquivos.saude.gov.br/images/ pdf/2017/janeiro/04/Plano-eliminacao-malaria-pub.pdf>

Savage, HME, E Rejmankova, Jl Arredondo-Jimenez, DR Roberts \& MH Rodriguez, 1990. Limnological and botanical characterization of larval habitats for two primary malarial vectors, Anopheles albimanus and Anopheles pseudopunctipennis, in coastal areas of Chiapas state, Mexico. Journal of the American Mosquito Control Association, 6: 612-620. Available on: https://www. biodiversitylibrary.org/content/part/JAMCA/JAMCA_V06_ N4_P612-620.pdf

Silva, AN, CC Santos, RN Lacerda, EPS Rosa, RT Souza, D Galiza, I Sucupira, JE Conn \& MM Póvoa, 2006. Laboratory colonization of Anopheles aquasalis (Diptera: Culicidae) in Belém, Pará, Brazil. Journal of the Medical Entomology, 43: 107-109. DOI: https://doi.org/10.1603/00222585(2006)043[0107:LCOAAD]2.0.CO;2

Silva, AR, PL Tauil, JLB Bastos-Júnior, WB Matos, EAP Costa \& EGR Gonçalves, 2006. Aspects of the focal transmission of malaria in the Island of São Luis, Maranhão. Revista da Sociedade Brasileira de Medicina Tropical, 39: 250-254. DOI: https://doi.org/10.1590/S0037-86822006000300004

Sinka, ME, Y Rubio-Palis, S Manguin, AP Patil, WH Temperley, PW Gething, TV Boeckel, CW Kabaria, RE Harbach \& SI Hay, 2010. The dominant Anopheles vectors of human malaria in the Americas: occurrence data, distribution maps and bionomic précis. Parasites and Vectors, 3: 72. DOI: https://doi.org/10.1186/1756-3305-3-72

Siqueira, AF, 1960. Estudos sobre a reação de precipitina aplicada à identificação de sangue ingerido por triatomíneos. Revista do Instituo de Medicina Tropical de São Paulo, 2: 41-53.

Snounou, G, S Viriyakosol, PX Zhu, W Jarra, L Pinheiro, VE Rosário, S Thaithong \& KN Brown, 1993. High sensitivy of detection of human malaria parasites by the use of nested polymerase chain reaction. Molecular and Biochemical Parasitology, 61: 315-320. DOI: https://doi.org/10.1016/0166-6851(93)90077-B

Soleimani-Ahmadi, M, H Vatandoost \& M Zare, 2014. Characterization of larval habitats for anopheline mosquitoes in a malarious area under elimination program in the southeast of Iran. Asian Pacific Journal of Tropical Biomedicine, 4: 73-80. DOI: https://doi.org/10.12980/ APJTB.4.2014C899

Tadei, WP \& B Dutary-Thatcher, 2000. Malaria vectors in the Brazilian Amazon: Anopheles of the subgenus Nyssorhynchus. Revista do Instituto de Medicina Tropical de São Paulo, 42: 87-94. DOI: https://doi.org/10.1590/ S0036-46652000000200005

Tadei, WP, B Dutary-Thatcher, JMM Santos, VM Scarpassa, IB Rodrigues \& MS Rafael, 1998. Ecologic observations on anopheline vectors of malaria in the Brazilian Amazon. American Journal of Tropical Medicine and Hygiene, 59: 
325-335. DOI: https://doi.org/10.4269/ajtmh.1998.59.325

Tadei, WP, IB Rodrigues, MS Rafael, RTM Sampaio, HG Mesquita, VCS Pinheiro, JAC Zequi, RA Roque \& JMM Santos, 2017. Adaptative processes, control measures, genetic background, and resilience of malaria vectors and environmental changes in the Amazon region. Hydrobiologia, 789: 179-196. DOI: https://doi.org/10.1007/ s10750-016-2960-y

Tadei, WP, JMM Santos, VM Scarpassa \& IB Rodrigues, 1993. Incidence, distribution and ecological aspects of Anopheles species (Diptera: Culicidae) in natural areas and environmental impact in the Brazilian Amazon, p. 167196. In: Ferreira, EJG, GM Santos, ELM Leão \& LA Oliveira (Eds). Bases científicas para estratégias de preservação e desenvolvimento da Amazônia. $1^{\text {st }}$ ed. Manaus: Instituto Nacional de Pesquisas da Amazônia, 371 p.

Tadei, WP, JMM Santos, WLS, Costa \& VM Scarpassa, 1988. Biologia de anofelinos amazônicos XII. Ocorrência de espécies de Anopheles, dinâmica de transmissão e controle da malária na zona urbana de Ariquemes (Rondônia). Revista do Instituto de Medicina Tropical de São Paulo, 30: 221-251.

Vezenegho, SB, A Adde, VP Santi, J Issaly, R Carinci, P Gaborit, I Dusfour, R Girod \& S Briolant, 2016. High malaria transmission in a forested malaria focus in French Guiana: How can exophagic Anopheles darling thwart vector control and prevention measures? Memórias do Instituto Oswaldo Cruz, 111: 561-569. DOI: https://doi.org/10.1590/0074-02760160150
Vittor, AY, RH Gilman, J Tielsch, G Glass, T Shields, WS Lozano, V Pinedo-Cancino \&JA Patz, 2006. The effect of deforestation on the human-biting rate of Anopheles darlingi, the primary vector of Falciparum malaria in the Peruvian Amazon. The American Journal of Tropical Medicine and Hygiene, 74: 3-11. DOI: https://doi.org/10.4269/ajtmh.2006.74.3

Vittor, AY, W Pan, RH Gilman, J Tielsch, G Glass, T Shields, W Sánchez-Lozano, VV Pinedo, E Salas-Cobos, S Flores \& JA Patz, 2009. Linking deforestation to malaria in the Amazon: characterization of the breeding habitat of the principal malaria vector, Anopheles darlingi. The American Journal of Tropical Medicine and Hygiene, 81: 5-12. DOI: https://doi.org/10.4269/ajtmh.2009.81.5

Xavier, MMSP \& JMM Rebêlo, 1999. Espécies de Anopheles (Culicidae, Anophelinae) em área endêmica de malária, Maranhão, Brasil. Revista de Saúde Pública, 3: 535-541. DOI: https://doi.org/10.1590/S0034-89101999000600003

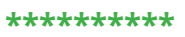

Suggestion citation:

Barros, VLL de, FM da Costa, AR da Silva, EGR Gonçalves, DS Bezerra, ES Lorosa \& WP Tadei, 2020. Study of behavioral patterns and infection analyses in anopheline species involved in the transmission of malaria in Buriticupu and São José de Ribamar municipality, Maranhão State, Brazil. EntomoBrasilis, 13: e0820.

Available on: doi: 10.12741/ebrasilis.v13.e0820
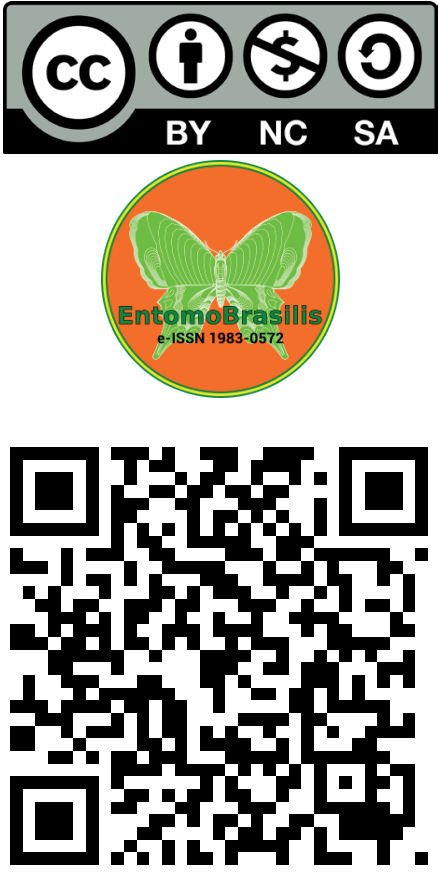